\title{
Expression of $c$-fos, Tyrosine Hydroxylase, and Neuropeptide mRNA in the Rat Brain around Birth: Effects of Hypoxia and Hypothermia
}

\author{
THOMAS RINGSTEDT, LIE-QI TANG, HÅKAN PERSSON, ${ }^{1}$ URBAN LENDAHL, AND \\ HUGO LAGERCRANTZ
}

Department of Biochemistry, Laboratory of Molecular Neurobiology [T.R., H.P.], Department of Woman \& Child Health [T.R., L.-Q.T., H.L.], and Department of Cell and Molecular Biology [U.L.], Karolinska Institute, Stockholm, Sweden

\begin{abstract}
Arousal at birth is likely to be accompanied by changes in gene expression patterns in the brain. We analyzed the expression levels of genes that may be involved in neonatal adaptation. We have also tried to dissect the effect of hypoxia and hypothermia, two components that may play a role in gene expression at birth. Therefore, we analyzed the expression patterns of the $c$-fos, tyrosine hydroxylase, enkephalin, preprotachykinin-A, and neuropeptide $\mathrm{Y}$ genes in various brain regions of rat pups at various time points after cesarean section under normal conditions and after exposure to hypoxia and hypothermia. We found that $c$-fos RNA was up-regulated transiently after birth in neocortex, midbrain, and pons-medulla with a maximum of 30 min after cesarean section, and that this transient increase was not further
\end{abstract}

augmented by hypoxia and hypothermia. The expression patterns of the other genes were not significantly altered, with the exception of a very slight increase in tyrosine hydroxylase RNA levels. We discuss tentative mechanisms for the transient increase in $c$-fos expression and the possible involvement of catecholamines in this process. (Pediatr Res 37: 15-20, 1995)
TH, tyrosine hydroxylase
Abbreviations
P1, P2 etc., number of days after birth
PPT-A, preprotachykinin-A
NPY, neuropeptide Y
d.p.c., days postcoitum

Birth represents a major transition in many important body functions, e.g. digestion, metabolism, respiration, and temperature regulation (for review see Ref. 1). The newborn infant is aroused and awakened from its mainly asleep state in the uterus, a process probably related to the activation of the locus coeruleus $(2,3)$, and accompanied by a surge of catecholamines and other neuroendocrine hormones (4).

Several changes in gene expression patterns around birth have been recorded. PPT-A RNA was found to be up-regulated about 4-fold in the respiratory nucleus tractus solitarius after birth in rabbit pups $(5,6)$. This is of interest because substance $\mathrm{P}$, which is translated from one of the mRNA from the PPT-A gene, is the dominant neuropeptide in these main respiratory nuclei and acts as a respiratory stimulatory agent (7). This change in expression was not observed in pups who were not breathing, and the expression of PPT-A RNA was not changed

Received March 3, 1994; accepted July 22, 1994

Correspondence: Dr. Hugo Lagercrantz, Department of Woman \& Child Health, Karolinska Institute, S-171 76 Stockholm, Sweden.

Supported in part by research grants from the Swedish Medical Research Council (5234), the Society for Child Care (H.L.), Magn. Bergvalls Stiftelse (H.L., U.L.) and the Swedish Cancer Society, Axel och Margaret Ax:son Johnsons Stiftelse, and Kjell och Märta Beijers Stiftelse (U.L.).

${ }^{1}$ Deceased. in nonrespiratory brain nuclei around birth (6). In another study the RNA for $\mathrm{TH}$, which is the rate-limiting enzyme in the catecholamine synthesis, was shown to increase about 4-fold in the adrenal medulla after $12 \mathrm{~h}$ in newborn rats (8). Similar increases were observed for RNA from the dopamine $\beta$-hydroxylase and NPY genes in the adrenal medulla (8).

Expression of the protooncogene $c$-fos, one of the immediate early genes, is known to be increased at birth in several tissues, including brain (9). This increased expression is attributed to the external stimuli after birth and possibly also to the catecholamine surge at birth (9). Levels of $c$-fos RNA were also found to be increased in corticotropin-releasing hormone neurons in the fetal sheep hypothalamus just before birth, suggesting that $c$-fos may be involved in the onset of labor (10). Expression of $c$-fos has also been shown to occur concomitant with brain seizures, which may argue for a role of $c$-fos in neuronal activity (11).

In this study we wanted to investigate in more detail the expression of $c$-fos, TH, PPT-A, enkephalin, and NPY genes in newborn rats. Expression levels were analyzed separately from three different brain regions: neocortex, striatumdiencephalon, and pons-medulla. These regions were selected because, first, the neocortex is postulated to be 
aroused at birth, second, hypothalamus is part of the striatum-diencephalon samples and, finally, autonomic functions are largely regulated in the pons-medulla. We also dissected the effects of hypoxia and hypothermia, which often occur in relation to birth.

\section{METHODS}

Animals. Sprague-Dawley rats were used throughout the experiments, and the animals were cared for in compliance with the National Institutes of Health guidelines for animal experiments. Pregnant rats were killed on the $22 \mathrm{nd} d$ after fertilization (21.5 d.p.c.) and the pups delivered in less than 5 min by cesarean section. To establish the expression profiles transiently after birth, some pups were killed immediately and others after $10 \mathrm{~min}, 30 \mathrm{~min}, 1 \mathrm{~h}, 2 \mathrm{~h}$, and $4 \mathrm{~h}$ under normoxic conditions at $38^{\circ} \mathrm{C}$. All pups were constantly observed and were breathing well after $30 \mathrm{~min}$. To study the influence of hypoxia and hypothermia, a second set of experiments was performed and pups, which were delivered by cesarean section at 21.5 d.p.c., were divided into three groups and subjected to three experimental settings. One group was transferred within $1 \mathrm{~min}$ after delivery to $38^{\circ} \mathrm{C}$ under normoxic conditions as control, the second group was transferred to $38^{\circ} \mathrm{C}$ in a hypoxic environment ( $9 \%$ oxygen in nitrogen), and the third group was transferred to $22^{\circ} \mathrm{C}$ in a normoxic environment. After $1 \mathrm{~h}$ the pups were immediately killed and RNA extracted (see below). Less than $5 \%$ of the pups died during hypoxia and hypothermia and these animals were not included in the study. For each time point under the different conditions, three independent experiments, each with eight to 16 animals, were performed.

Preparation of tissue and RNA extraction. The brains of the killed animals were dissected out and quickly divided into three areas: neocortex, striatum-diencephalon, and ponsmedulla. In each experiment, the samples from each area were frozen on dry ice and pooled $(n=8-16)$. The tissue samples were homogenized with a Polytron in $4 \mathrm{M}$ guanidine isothiocyanate, $0.1 \mathrm{M} \beta$-mercapthoethanol, $0.025 \mathrm{M}$ sodium citrate, $\mathrm{pH} 5.5$, layered on top of a $\mathrm{CsCl} /$ citrate cushion and centrifuged at $15^{\circ} \mathrm{C}$ in a Beckman SW41 rotor at 35,000 rpm for 21 $h$ (12). The total RNA was dissolved and the poly $\mathrm{A}^{+}$fraction purified by conventional oligo-dT column chromatography (13). The amounts of ribosomal RNA still present in the polyA $^{+}$fraction after this purfication procedure were very reproducible and were used to assess the integrity of the RNA and to quantitate loadings on the Northern blot gels (see below). The concentration of RNA was estimated by spectrophotometry at $260 \mathrm{~nm}$. RNA from each sample $(10 \mu \mathrm{g})$ was electrophoresed in $1 \%$ agarose gels containing $0.7 \%$ formaldehyde and $500 \mathrm{ng} / \mathrm{mL}$ ethidium bromide and photographed under UV-light. The intensity in the ethidium bromide staining in the 28S RNA band was quantitated using a Leica Quantimet 570 system (Cambridge Instruments, Cambridge, UK) and used to normalize the amounts of RNA loaded (see below).

Northern blot hybridization. After gel electrophoresis, the RNA was transferred to nitrocellulose filters as previously described (12). After baking in vacuum for $2 \mathrm{~h}$ at $80^{\circ} \mathrm{C}$ the filters were prehybridized for $1 \mathrm{~h}$ at $43^{\circ} \mathrm{C}$ in $4 \times \mathrm{SSC}(1 \times \mathrm{SSC}$ $=0.15 \mathrm{M} \mathrm{NaCl}$ and $0.015 \mathrm{M}$ sodium citrate, $\mathrm{pH} 7.0), 40 \%$ formamide, $1 \times$ Denhardt's solution $(50 \times$ Denhardt's solution $=5 \mathrm{~g} / \mathrm{L}$ of BSA, polyvinylpyrrolidone, and Ficoll), $10 \%$ dextran sulfate, and $150 \mu \mathrm{g} / \mathrm{mL}$ of denatured sheared salmon sperm DNA for $1 \mathrm{~h}$ at $43^{\circ} \mathrm{C}$ to block nonspecific binding of the probe. The prehybridization solution was then replaced with the hybridization solution (same composition as the prehybridization solution) containing the probe, labeled by nick translation (14) to a sp act of $5 \times 10^{8} \mathrm{dpm} / \mu \mathrm{g}$ at a concentration of $2 \times 10^{6} \mathrm{dpm}$ probe/mL hybridization solution. Rat cDNA probes for the TH, PPT-A, and NPY genes, a mouse cDNA clone for $c$-fos, and a human clone for the enkephalin gene were used as probes. After hybridization for more than $16 \mathrm{~h}$ at $43^{\circ} \mathrm{C}$ the filters were washed at high stringency (final wash $=$ $0.1 \times \mathrm{SSC}, 0.1 \% \mathrm{SDS}, 2 \times 30 \mathrm{~min}$ at $55^{\circ} \mathrm{C}$ ) for the $\mathrm{TH}$, PPT-A, and NPY probes and at moderate stringency (final wash $=0.2 \times \mathrm{SSC}, 0.1 \% \mathrm{SDS}, 2 \times 30 \mathrm{~min}$ at $50^{\circ} \mathrm{C}$ ) for the $c$-fos and enkephalin probes. The filters were then exposed to Kodak X-AR5 film at $-70^{\circ} \mathrm{C}$ for various time periods to ensure that the signal on the $\mathrm{X}$-ray film was in the linear range. The autoradiograms were quantified using a Shimadzu CS9000 densitometer (Shimadzu, Kyoto, Japan) or a Leica Quantimet 570 image analysis system. To compensate for variations in the loading of RNA, the hybridization signal was normalized to the amounts of $28 \mathrm{~S}$ RNA estimated from the ethidum bromide staining of the gel. To compare data from the individual experiments in the presentation of the data, the hybridization signal for $0 \mathrm{~h}$ after birth was set to 1 and the results from other time points in the same experiment were recalculated accordingly. In some cases, the RNA yield from an experiment was enough to run more than one gel, and the results from the resulting autoradiograms were averaged after they had been normalized separately. As an additional control for standardization, all filters were stripped and rehybridized with a rat $\beta$-actin probe at high stringency. The results from this rehybridization were generally in very good agreement with the 28S RNA data (data not shown).

Statistics. The nonparametric Mann-Whitney test was used to statistically compare the different data. $p<0.05$ was regarded as significantly different.

\section{RESULTS}

We used Northern blot hybridization to analyze the levels of the different RNA in rat pups during the first hours after cesarean section and after exposure to hypoxic and hypothermic conditions. In all cases, the probes identified mRNA of the expected lengths: $2.2 \mathrm{~kb}$ ( $c$-fos), $1.9 \mathrm{~kb}(\mathrm{TH}), 1.5 \mathrm{~kb}$ (enkephalin), $1.0 \mathrm{~kb}$ (NPY), and $1.3 \mathrm{~kb}$ PPT-A (Fig. 1). As a control, a filter was rehybridized with an actin probe, which identified the expected $2.0 \mathrm{~kb}$ mRNA.

Gene expression after cesarean section. Rat pups were delivered by cesarean section at 21.5 d.p.c., and expression of $c$-fos, TH, enkephalin, NPY, and PPT-A was analyzed immediately $(0 \mathrm{~h}$ ) and after $10 \mathrm{~min}, 30 \mathrm{~min}, 1 \mathrm{~h}, 2 \mathrm{~h}$, and $4 \mathrm{~h}$ in a normoxic, thermoneutral $\left(38^{\circ} \mathrm{C}\right)$ environment. The most notable difference in gene expression was a transient increase in 


\section{Pons-medulla}

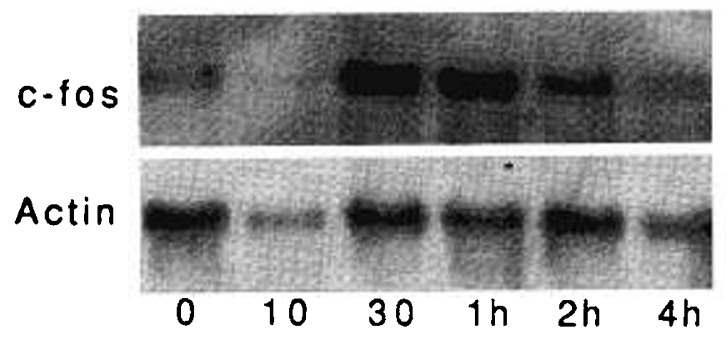

Midbrain

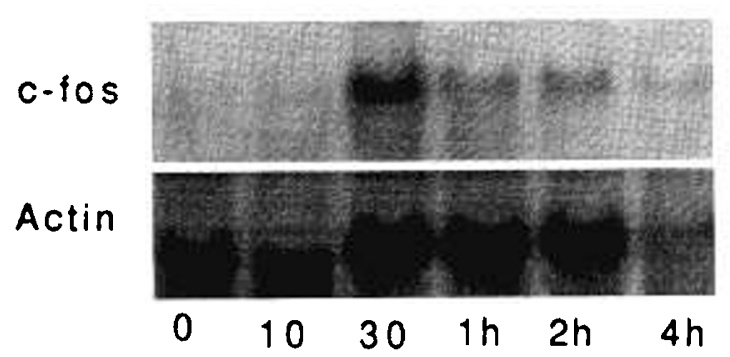

Neocortex

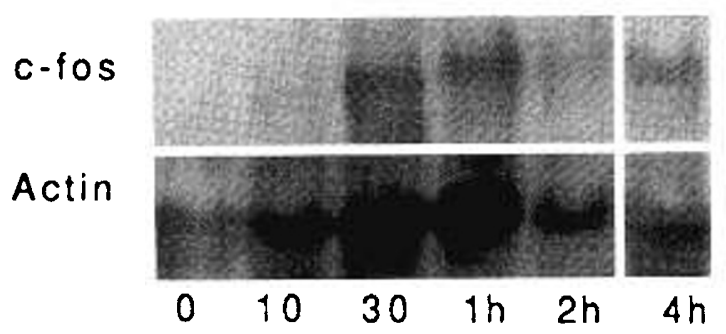

Figure 1. Northern blot analysis of brain RNA hybridized with the different probes. Ten $\mu \mathrm{g}$ of poly $\mathrm{A}^{+} \mathrm{RNA}$ from neocortex $1 \mathrm{~h}$ after birth were hybridized with probes for actin, $c-f o s$, enkephalin, NPY, PPT-A, and TH. To the left, the ethidium bromide staining of a gel is shown, and the positions of the $28 \mathrm{~S}$ and $18 \mathrm{~S}$ rRNA bands are indicated.

c-fos RNA expression in both neocortex, striatum-diencephalon, and pons-medulla (Fig. 2). The highest levels in all three brain regions were recorded at $30 \mathrm{~min}$ with median values 2.5 to 4.5 times as high as in animals killed immediately after cesarean section. This increase was statistically significant in all three brain areas as determined by the Mann-Whitney test ( $p$ $<0.05$ ). After $1 \mathrm{~h}$, the $c$-fos RNA levels had decreased somewhat, but the median $c$-fos RNA levels in neocortex and pons-medulla were still higher than at $0 \mathrm{~h}$. At $4 \mathrm{~h}$, the $c$-fos RNA levels had returned to the same level as at $0 \mathrm{~h}$ in all three brain regions (Fig. 2).

Changes in expression of the other genes were not as pronounced as for $c$-fos, but a slight increase in TH expression was observed, although it was not statistically significant (data not shown). Similarly, the expression of NPY and enkephalin RNA increased slightly in some of the experiments (data not shown). RNA levels for PPT did not undergo detectable changes in this study (data not shown).
Gene expression under hypoxic and hypothermic conditions. To dissect the effects of the transition at birth on gene expression in more detail, rat pups delivered by cesarean section were exposed to hypoxic or hypothermic conditions. When analyzed $1 \mathrm{~h}$ after exposure to hypoxia (9\% oxygen in nitrogen at $38^{\circ} \mathrm{C}$ ), the median $c$-fos levels showed an increase in neocortex and pons-medulla compared with the levels at $0 \mathrm{~h}$ $(p<0.05)$, although the increase was less dramatic in striatumdiencephalon (Fig. 3). The increase was comparable to that seen $1 \mathrm{~h}$ after cesarean section under normoxic conditions. A single experiment after $30 \mathrm{~min}$ in hypoxia showed even higher c-fos levels in striatum-diencephalon and pons-medulla (data not shown), which were comparable to those seen under normoxic conditions. The TH RNA levels were somewhat increased after hypoxia in neocortex and striatum-diencephalon, although the increase was not statistically significant.

The data from exposure to hypothermia $\left(22^{\circ} \mathrm{C}\right.$ in a normoxic environment) were very similar to the hypoxic situation (Fig. 3). A statistically significant increase in $c$-fos RNA levels, compared with the $0 \mathrm{~h}$ control $(p<0.05)$, was seen after $1 \mathrm{~h}$ of exposure to hypothermia in neocortex and striatumdiencephalon. The increase was comparable to that seen after 1 $\mathrm{h}$ in normal temperature. In a single experiment, a similar increase was seen after $30 \mathrm{~min}$.

Our experiments did not show any significant changes in the RNA levels for the other genes after exposure to hypoxia and hypothermia (data not shown). Although the median TH RNA levels were three times higher in the hypoxic compared with the normoxic animals after $1 \mathrm{~h}$, the difference was not significant (data not shown).

\section{DISCUSSION}

The aim of this study was to analyze changes in the expression of some neuroactive genes possibly involved in the arousal and onset of homeostatic functions at birth. It is generally assumed that adaptations to the new environment largely occur in the CNS, and therefore we analyzed three anatomically and functionally distinct areas: neocortex, diencephalon-striatum, and pons-medulla. We also wanted to examine the transition to the extrauterine environment in more detail and therefore analyzed the effects of $1 \mathrm{~h}$ of exposure to hypoxia, hypothermia, and normoxic, isothermic conditions after birth.

The most important finding was that $c$-fos RNA levels are transiently increased after birth, both after cesarean section under normal conditions and after cesarean section followed by hypoxia and hypothermia. This transient increase may be important for gene regulation at birth because the $c$-fos protein is a transcription factor that is involved in activating other genes, e.g. collagen, collagenase, and $c-m y c$, by binding to control elements in their promotors (see Ref. 15 for review). Previous studies in the mouse have demonstrated an upregulation of $c$-fos RNA after birth in several tissues, including brain $(9,16)$. In the study by Kasik et al. (9), c-fos RNA was detected in the brain on the day of birth and P1 and then increased in P3 and P5 animals. Our study extends this observation by showing that there is also a transient peak of $c$-fos 

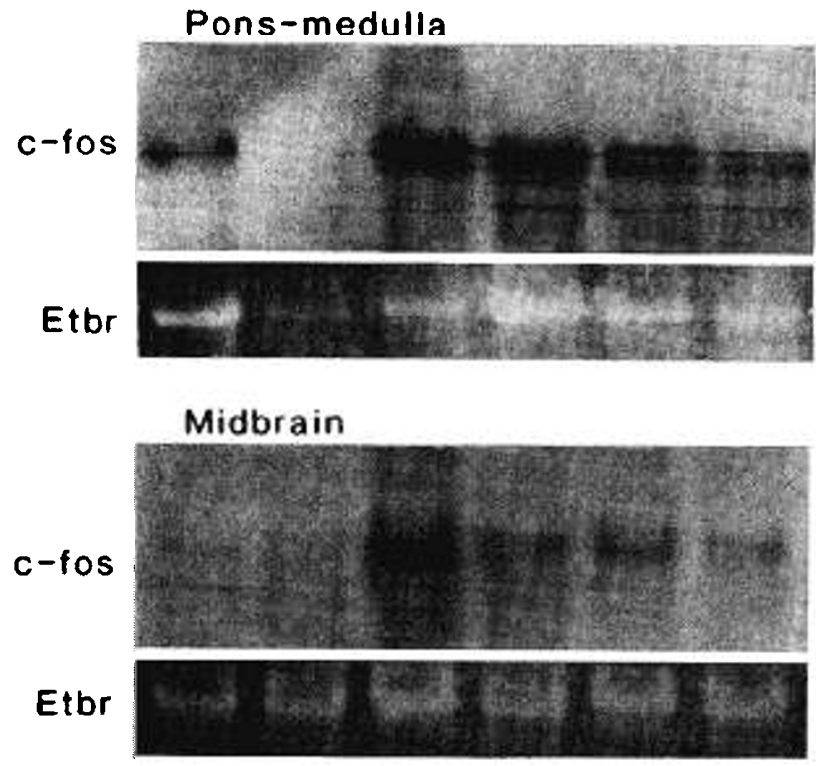

Cortex

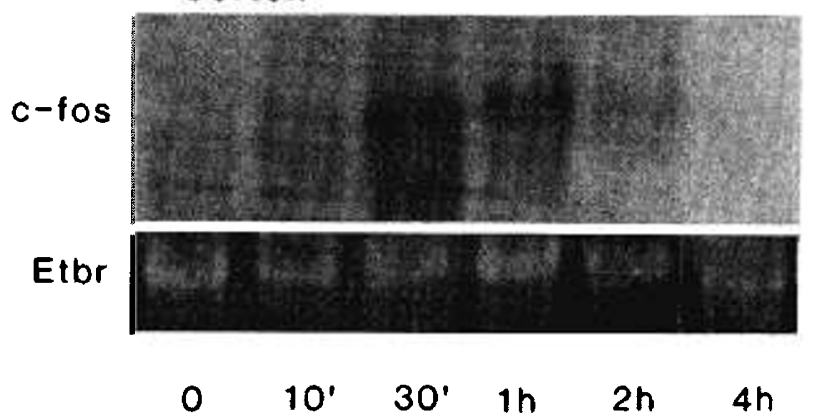

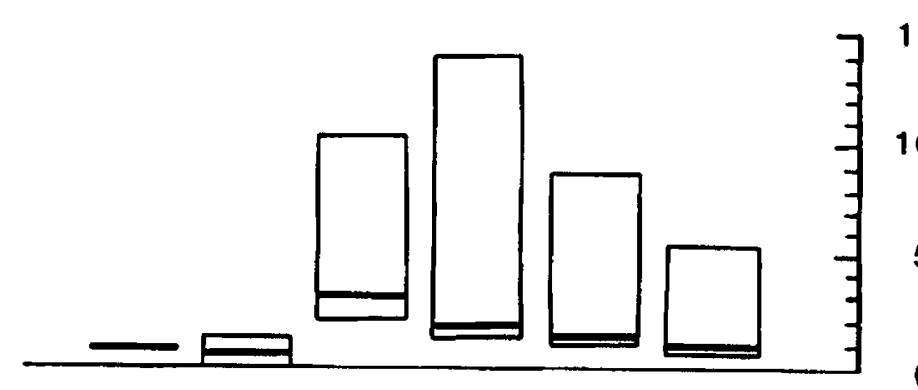
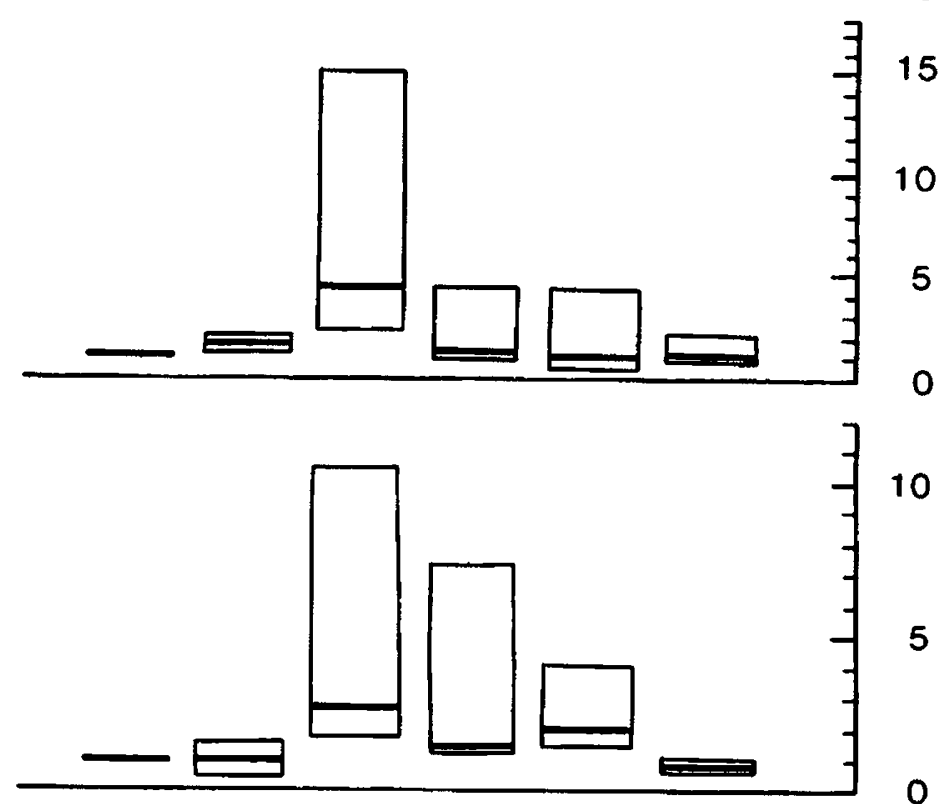

Figure 2. Northern blot analysis of brain RNA hybridized with the $c$-fos probe at different time points after cesarean section. To the left is shown a Northern blot analysis of $10 \mu \mathrm{g}$ of polyA ${ }^{+}$RNA from neocortex, striatum-diencephalon, and pons-medulla at $0,10,30$, and 60 min and 2 and $4 \mathrm{~h}$ after cesarean section hybridized with the $c$-fos probe. The ethidium bromide staining (EtBr) of the $28 \mathrm{~S}$ rRNA band from the same lanes is shown below each blot. To the right, the densitometric scannings of three independent experiments are shown (one of which is shown to the left). The maximum, minimum, and median (thick horizontal bar) values are plotted. The values at 0 min were set to 1 and all other values recalculated accordingly (see Methods).

expression $30 \mathrm{~min}$ after cesarean section. This transient peak is similar to the $c$-fos expression profile in mouse liver after cesarean section, which showed the highest levels of $c$-fos RNA 60 min after cesarean section (16). Although we cannot strictly rule out a species difference in $c$-fos expression between rat and mouse, it seems likely that $c$-fos in brain has a biphasic mode of expression with a transient peak within $1 \mathrm{~h}$ after birth followed by the previously described slower surge over the first few postnatal days. This transitory increase of $c$-fos might be sufficient to trigger mechanisms involved in the neonatal adaptation.

Our experiments showed that hypoxia and hypothermia did not further elevate the transient increase in $c$-fos expression, because the levels of $c$-fos RNA were approximately the same in the different experimental settings. It has previously been shown that the $c$-fos gene can be activated by a specific transcription factor, the serum response factor, which binds to the serum response element in the $c$-fos enhancer (see Ref. 15 for review). The situation in neonatal induction may, however, be different and involve also binding of another transcription factor (16). It will be interesting to establish which combina- tion of transcription factors mediates the transient induction after birth.

Our data suggest that the physiologic stimulus of $c$-fos expression is derived from the transition from intra- to extrauterine environment per se rather than from changes in oxygen and temperature conditions. The use of cesarean section also eliminated the possible effects on $c$-fos induction caused by mechanical stress on the fetus during vaginal delivery. The $c$-fos induction could be caused by a general increase of the somatosensory input and subsequently augmented neuronal activity in the brain. In this context, it is interesting to recall that synaptic activity can act as an inducer of $c$-fos expression in hippocampus (11).

Catecholamines have also been considered as a possible inducer of $c$-fos expression, because their levels are markedly elevated at birth $(4,17)$. However, it is likely that the situation is more complex, because the surge of catecholamines may partly result from the oxygen deficiency associated with birth (4), and the c-fos RNA levels were not further increased at hypoxic conditions. Our findings of only a relatively small increase in TH RNA levels may suggest that the increased 

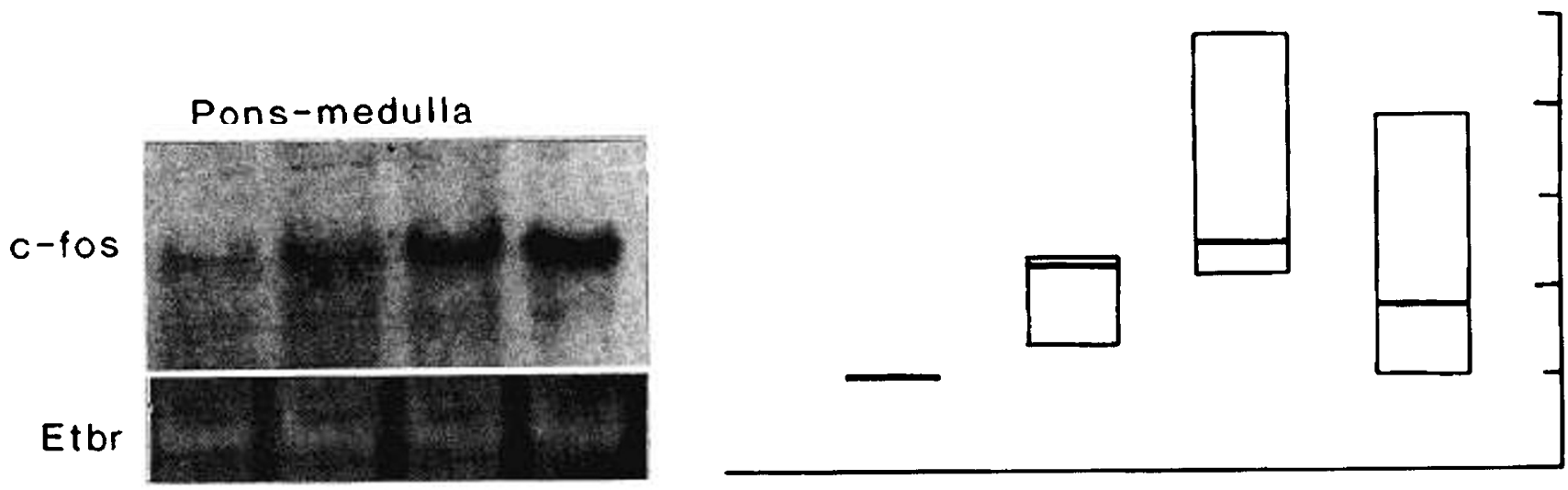

\section{Midbrain}

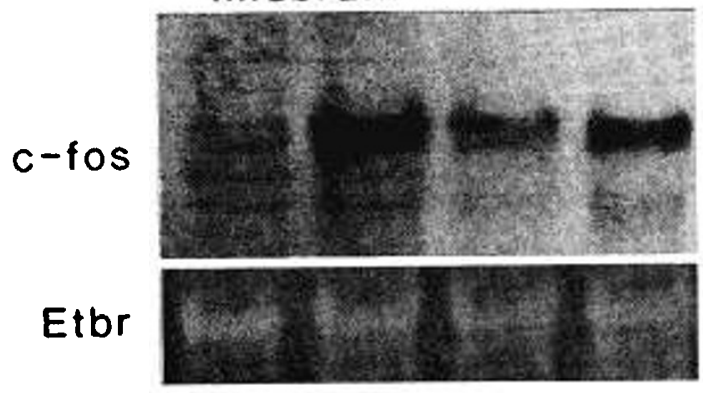

\section{Cortex}

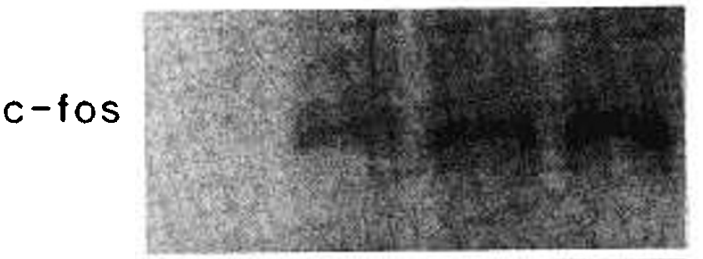

Etbr

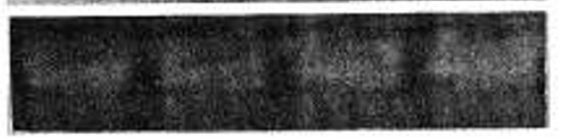

0

$1 \mathrm{~h}$

ht

$9 \%$

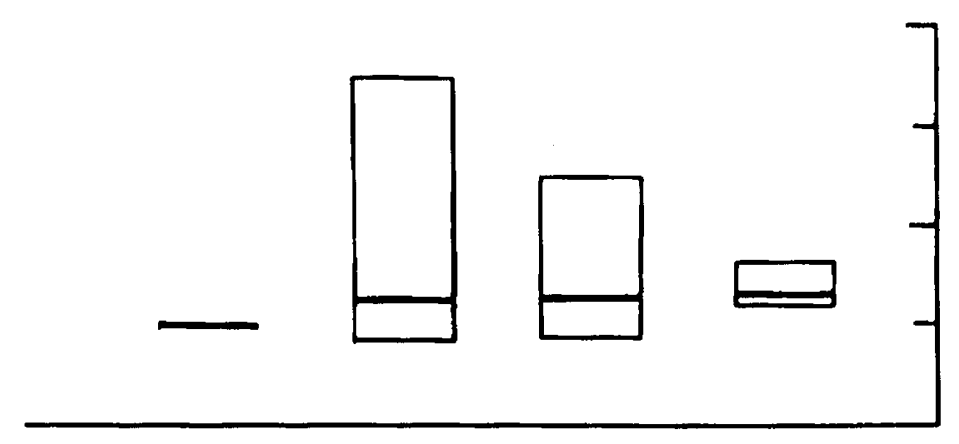

Figure 3. Northern blot analysis of brain RNA after hypoxia and hypothermia hybridized with the $c$-fos probe. To the left is shown a Northern blot analysis of $10 \mu \mathrm{g}$ of polyA ${ }^{+}$RNA from neocortex, striatum-diencephalon, and pons-medulla at $0 \mathrm{~min}$ and after $1 \mathrm{~h}$ at $38^{\circ} \mathrm{C}$ under normoxic conditions $(I \mathrm{~h})$, after $1 \mathrm{~h}$ in a normoxic environment at $22^{\circ} \mathrm{C}(h t)$, and after $1 \mathrm{~h}$ at $9 \%$ oxygen in nitrogen at $38^{\circ} \mathrm{C}(9 \%)$. The ethidium bromide staining $(E t B r)$ of the $28 \mathrm{~S}$ rRNA band from the same lanes is shown below each blot. To the right, the densitometric scannings of three independent experiments are shown (one of which is shown to the left). The maximum, minimum, and median values are plotted. The values at 0 min were set to 1 and all other values recalculated accordingly (see Methods).

turnover of catecholamines in the newborn brain (3) is not coupled with the transcriptional control of the $\mathrm{TH}$ gene, but may involve posttranscriptional regulation of $\mathrm{TH}$ protein levels. We also cannot exclude that a surge in $\mathrm{TH}$ occurs later during development. It should also be emphasized that pups in all experiments were delivered by cesarean section and that the absence of labor leads to a smaller surge in catecholamines.

We observed very small, statistically insignificant changes in expression of the various neuropeptide RNA, including PPT-A RNA. The latter finding was somewhat surprising given the data from newborn rabbit pups, in which PPT-A RNA has been shown to increase about 4-fold at the day of birth (6). This difference may be explained by a species difference between rat and rabbit pups. Rabbit pups, in contrast to rat pups, are precocial developers, and more closely resemble human infants with regard to the maturation of sleep-wakefulness cycles (18). The latter possibility could be addressed by analyzing PPT-A levels in rats at different time points after birth.

\section{REFERENCES}

1. Hanson MA 1991 The Fetal and Neonatal Brain Stem: Developmental and Clinical Issues. Cambridge University Press, Cambridge, UK

2. Svensson TH 1987 Peripheral, autonomic regulation of locus coeruleus noradrenergic neurons in brain: putative implications for psychiatry and psychopharmacology. Psychopharmacology 92:1-7

3. Lagercrantz H, Pequignot J, Pequignot J-M, Peyrin L 1992 The first breaths of air stimulate noradrenaline turnover in the brain of the newborn rat. Acta Physiol Scand 144:433-438 
4. Lagercrantz H, Slotkin TA 1986 The "stress" of being born. Sci Am 254:100-107

5. Brené S, Lindefors N, Friedman WJ, Persson H 1990 Preprotachykinin A mRNA expression in the rat brain during development. Brain Res Dev Brain Res 57:151-162

6. Srinivasan M, Yamamoto Y, Persson H, Lagercrantz H 1991 Birth-related activation of preprotachykinin-A mRNA in the respiratory neural structures of the rabbit. Pediat Res 29:369-371

7. Yamamoto $Y$, Lagercrantz $H 1985$ Some effects of substance $P$ on central respiratory control in rabbit pups. Acta Physiol Scand 124:449-455

8. Holgert H, Schalling M, Hertzberg T, Lagercrantz H, Hökfelt T 1991 Changes in levels of mRNA coding for catecholamine synthesizing enzymes and neuropeptide $Y$ in the adrenal medulla of the newborn rat. J Dev Physiol 16:19-26

9. Kasik JW, Wan Y-JY, Ozato K 1987 A burst of $c$-fos gene expression in the mouse occurs at birth. Mol Cell Biol 7:3349-3352

10. Hoffman GE, McDonald T, Shedwick R, Nathanielsz PW 1991 Activation of c-fos in ovine fetal corticotropin-releasing hormone neurons at the time of parturition. Endocrinology 129:3227-3233

11. Morgan JI, Cohen DR, Hempstead JL, Curran T 1987 Mapping patterns of $c$-fos expression in the central nervous system after seizure. Science 237:192-197

12. Maniatis T, Fritsch EF, Sambrook J 1989 Molecular Cloning: A Laboratory Manual. Cold Spring Harbor Laboratory, Cold Spring Harbor, NY

13. Aviv $H$, Leder P 1972 Purification of biologically active globin messenger RNA by chromotography on oligothymidylic acid-cellulose. Proc Natl Acad Sci USA 69:1408-1412

14. Rigby PWJ, Dieckmann M, Rhodes C, Berg P 1977 Labeling deoxy-ribonucleic acid to high specific activity in vitro by nick translation with DNA polymerase I. J Mol Biol 113:237-249

15. Rivera VM, Greenberg ME 1990 Growth factor-induced gene expression: The ups and downs of $c$-fos regulation. New Biol 2:751-758

16. Levi B-Z, Kasik JW, Burke PA, Prywes R, Roeder RG, Appella E, Ozato K 1989 Neonatal induction of a nuclear protein that binds to the $c$-fos enhancer. Proc Natl Acad Sci USA 86:2262-2266

17. Lagercrantz H, Bistoletti P 1977 Catecholamine release in the newborn. Pediatr Res 11:889-893

18. Shimizu A, Himwick HE 1968 The ontogeny of sleep in kitten and young rabbits. Electroencephalogr Clin Neurophysiol 24:307 -318

\section{Announcement \\ THE ASSOCIATION OF MEDICAL SCHOOL PEDIATRIC DEPARTMENT CHAIRMEN, INC. proudly announces the \\ Pediatric Scientist Development Program 1994 Fellows}

Name

Ron Jonathan Bahar, M.D.

Kevin Anderson Cassady, M.D.

Jane Wing-Sang Fang, M.D.

Johan K. Hitzler, M.D.

Patrick Sean McQuillen, M.D.

Stephen Edward Miles, M.D.
Sponsoring Department and Chairman

Edward McCabe, M.D., Ph.D. UCLA School of Medicine

Herbert Abelson, M.D. University of Washington

Douglas J. Barrett, M.D. University of Florida

Robert Haslam, M.D. Hospital for Sick Children

Lary J. Shapiro, M.D. University of California, San Francisco

Richard Lampe, M.D.

Texas Tech University

and

Pearay Ogra, M.D.

University of Texas Medical Branch at Galveston

We gratefully acknowledge the support and sponsorship of:

National Institute for Child Health and Human Development

March of Dimes Birth Defects Foundation

St. Jude Children's Research Hospital

American Academy of Pediatrics

Cystic Fibrosis Foundation

The Hospital for Sick Children Foundation

American Pediatric Society

The Burroughs Wellcome Fund 